\title{
Historical Perspective, Research in Higher Education
}

Vincent Carpentier

UCL Institute of Education, University College London, London, UK

\section{Synonyms}

The study of the past; the long-term lens; changes and continuities.

\section{Definition}

The study of the past of higher education.

\section{Introduction}

The engagement with history is an important feature of research in higher education, which has taken various forms and has been driven by various rationales (Lowe 2009). The variety of objectives, methodologies and interpretations is precisely what made the contribution of the historical dimension to the understanding of higher education so valuable although it has not come without its challenges.

\section{Past present and future}

Many factors explain why universities alongside other forms of higher education have always been the objects of a strong historical attention. To start with, Hammerstein reminds us that "European universities are the oldest surviving European institutions with the exception of the catholic Church" (1996, p.113).

\section{Past and present}

Although the historical perspective often confirms its strong potential to enrich the understanding of higher education, it does not escape from the key debates about the various conceptions of the role of history and its potential uses and misuses. Such debates question whether the use of history to inform the present is desirable or even feasible. The risk of presentism has been debated within most historical fields and the history of higher education is no exception (Hutcheson, 2010). Such controversies had the merits to sound a note of caution for those seeking to conduct or read historical research in higher education. First of all, they remind us of the intrinsic value of historical research in higher education and that "it was perfectly possible for historical explanations to be pursued for its own sake without reference to the claims of social relevance" (Tosh, p. 47). They also incite those seeking to link past and present to be mindful of the danger of a presentist view of history and its consequences in terms of misinterpretations or anachronisms. Those are problematic issues not only in relation to the validity of historical findings but also in relation to the ways findings "travel", and can sometimes be decontextualized as part of an instrumental and selective use of history by media and policy circles. Acknowledging those limitations does not weaken but strengthens a reasoned approach of history seeking to inform the present. This effort of contextualisation is an integral part of a necessary productive engagement of historians with public policy (Szreter, 2011, p. 222). 


\section{Periodisations}

The difficulty to make sense of such a long history is reflected by the variety of offered historical periodisations of higher education, which mirror the differences in the lens and the thematic chosen. The starting point of such periodization has also always been a recurrent issue. Many researchers like Perkin identified the rise of the university as turning point making the expansion of European higher education a distinctive phase in the global history of higher education (Perkin, 2007). However, it is important to acknowledge that European higher education has been influenced by higher learning not only in Europe itself dating back to Ancient Greece and Rome, but also from outside, with for instance, the influence of Egyptian, Chinese, Indian and Islamic institutions. Lowe and Yashura trace those influences back in their exploration of the origins of higher learning, which they explain by the development of international networks (2017).

Thus, the key aspect of the Middle Age is to represent a key moment of formalisation of higher education. The mediaeval university emerged as an autonomous corporation of learning closely associated to the professions before taking part of a more controlled and territorialised expansion along the feudal and religious lines $\left(12^{\text {th }}-15^{\text {th }}\right.$ centuries). A shift occurred during the early modern period as the university became associated with a stronger political rationale. As key drivers of the construction of Nation States, they were increasingly involved in dynastic and religious wars of the time $\left(16^{\text {th }}-18^{\text {th }}\right.$ centuries). During the late modern era (1789-1914), the university became strongly questioned and even destabilised by the political and economic revolutions (Musselin, 2004). This turbulent era led to the development (or revival) of non-university forms of higher education and the construction of national models reflecting the specificities of countries (Humboldt, Napoleonic, US) and their (voluntarily or involuntarily) exports across the globe in full or hybridised versions. During the post 1914 era, the new world created by the Great Depression and the two World Wars that framed it transformed higher education. The post 1945 expansion, and in some countries massification, of higher education has been associated with a series of massive transformations including the development of welfare states, the emergence of the knowledge economy and a third industrial revolution, the cold war and the movement of decolonisation and globalisation and the various crises of capitalism. The end of the cold war, the crisis of the 1970s and its shift towards low taxation economic policies combined with the intensification of the movement of globalisation has challenged many of the foundations of the post 1945 model. The global crisis of 2008 has shown the persistence of tensions between higher education, economy and society leading to a regain of historical interest. This suggests a clear interest in looking at such a long-term lens to contextualise the current debates. At the same time, the extent of the changes revealed by such periodization shows the difficulty in comparing different contexts. For example, comparing today's context with the 1960s is useful but must take on board the fact that enrolment rates were in most countries well below $10 \%$ at the time. There have been valuable attempts to offer frameworks seeking to connect rather than comparing past and present. For example, Välimaa's approach considers the historical development of higher education as the aggregation of historical layers (2007, p. 68). Other examples of lenses assisting the navigation of the long term include Trow's analysis of the origins and implications of the shift from elite towards mass and universal higher 
education (1974) or Watson's geological metaphor mapping up the institutional stratification of higher education systems (2014).

Thus, a reasoned historical contextualisation of higher education might consist in exploring the changes and continuities (Aldrich 2003) regarding the types of institutions, their missions and activities, the students and staff that populated them. The periodisation suggested above shows that those parameters has recurrently changed across history and at times in dramatic fashion. As a result, it is difficult to find a common language and name and interpret higher education across time.

\section{Definitions and boundaries}

According to Perkin, the slogan on the historian's banner is, or should be "Things change but names remain the same'. In no area of human experience is this concept truer than in the history of higher education" (1984, p.18). This is underlined by Silver who argues that "higher education may or may not be treated as including the seminary or teacher education, the long established or the new alternative, the major or the small or evanescent. It is not always clear what 'higher education' rather than the 'university' or the 'college' has meant" (2006, p. 123). Thus, the historical perspective appears useful when terms such as university and higher education tend to be used interchangeably. Acknowledging the historical difficulty of defining higher education and its boundaries might be a way not so much to reach a consensus but rather to be aware of alternative positions and recognising that we may not be talking about the same thing.

The research on medieval universities offers an interesting way of showing how both useful and problematic a historical contextualisation can be. Cobban indicates that before being associated with higher education, the term Universitas used to define "any kind of aggregate body of persons with common interests and independent legal status" (1975, p. 23). Universities therefore emerged as guild or corporation unions applied to higher education whose rights concerned the status of teachers and students, and their licences and titles. They were corporate developments of previous forms of higher learning such as the cathedral schools or the Studium Generale. Studium prefigured the first medieval universities as communities of teachers and students from various countries travelling across Europe and using Latin as a global language. Moreover, Verger defines a Studium as an "institution of higher education founded, or, at any rate confirmed in its status by, an authority of a universal nature, such as the pope or (less frequently), the Emperor, which enjoyed a certain numbers of rights, likewise universal in their application" (1992, p. 35). Thus, the question of autonomy and the right to act as a corporate body might have been the most distinctive feature of a university at this time.

Rashdall notes that Universitas and Studium were originally distinct terms, which became synonymous (1936). This offers a useful historical lens to the recurrent interrogations regarding the ways in which a university articulates its internal organisation with the influence and recognition from the external world (local, national or international). This echoes Kerr's idea that "much of the history of higher education is written by the confrontations of internal 
logic versus external pressures. Higher education has never been fully autonomous" (1994, p. $x v i)$.

\section{Historical perspectives on systems, institutions and people}

The increasing focus on the relationships and tensions between expansion, democratisation and differentiation is an opportunity to reflect on the historical dynamics that links higher education systems, their institutions and their people.

The historical drivers behind the expansion of higher education systems:

The historical perspective is an opportunity to reflect on the connections and tensions between the political, social and economic rationales of higher education. The links between higher education, society and the economy has been widely studied. Political histories of higher education explored the evolution of the State and the market (Palfreyman and Tapper; Shattock 2012; Musselin 2004). The contribution of the historical perspective to the understanding of the relationship between higher education and social change has been widely recognised (Brennan, 2008) while research on the historical link between higher education and the economy (Sanderson 1972) has recorded a renewed interest. This includes a closer focus on the ways in which higher education is connected not only wealth creation but also to its distribution. Such question is at the centre of Goldin and Katz's studies of the long term race between education and technology (2008) as well as Piketty' historical work on the origins and consequences of inequalities (2014). Those historical reflections on the current connections and tensions between the political, social and economic drivers of higher education helps thinking about the ways in which higher education is perceived, organised and funded (Carpentier, 2012) and the influence on key issues such as the balance between the public/private good of higher education (Marginson, 2011).

\section{Institutional differentiation across history}

The increasing interest in the connection and tension between expansion and stratification has reinforced the historical study of institutions or groups of institutions. Tight claims that "institutional histories of individual universities and colleges are one of the staples of the higher education literature" (2012, p. 136). Thelin notes that "colleges and universities are historical institutions. They may suffer amnesia or may have selective recall, but ultimately heritage is the life blood of our campuses" (2004, p.xxi).

The study of the various types of institutions has focused on the emergence in the $19^{\text {th }}$ century of new types of universities in institutions such as civic universities (Vallance, 2016) and community colleges (Beach 2011). History of differentiation and diversity are good lenses to understand the various models of higher education such as the British binary system (Scott, 2014), the French interface between universities and Grandes Ecoles (Musselin 2004) and the role of community colleges in the US system with the key example of California (Geiger 2015; Marginson 2016). The History of private HE shows how difficult it is to compare private provision across time and space (Teixeira 2009). One of the key questions raised by those works is whether differentiation is the historical product of the needs for diversity of mission or responds a form of channelling inequalities or both. 
Higher education and its people and the question of democratisation

Jarausch argues that the history of higher education "needs to be firmly integrated into the general discussion of social change in order to determine the university's contribution to 'modernization' as well as to the perpetuation of traditional elites, values and styles" (1983, p. 11). This agenda has been consolidated by many historical studies examining the connections and tensions between the process of expansion and democratisation of higher education through the story of historically underrepresented groups. The voices of those groups, previously excluded from historical accounts, have been slowly recovered by studies on history of women in higher education (Dyhouse, 2006), social class (Anderson 1992), ethnicity (Smyth et al. 2002) and disability (Madaus 2011). Other voices include the history of international students (Bevis and Lucas 2007). History of academic staff (Charle 1994; Halsey 1992 ) is also an important of research with a notable focus on gender (von Oertzen 2014) and a rather unexplored history of professional staff.

\section{Approaches}

The multiple dimensions of higher education and the disciplines

Higher education is multidimensional and its understanding requires various lenses. Historical research in higher education takes place in many places including in various branches of history and across disciplines. Picard argues for a global approach to history of higher education in France, which would incorporate the political, cultural, economic and social lenses (2009).

\section{Methods and sources}

According to Tosh, "historical sources encompass every kind of evidence that humans have left us of the past activities (Tosh, 2006, p. 58). The formidable amount and variety of historical data generated in higher education setting is a wonderful prospect but raises significant challenges. A range of quantitative and qualitative data historical research has been left by individuals and institutions involved in higher education. Those includes memoirs, letters from staff, students, managers and policy makers but also from institutional and policy documents (minutes, official documents, statistics, reports) as well as the media coverage (newspaper, video), artefacts and architecture (Whyte 2015). Those data are socially constructed and often closely associated to power and bureaucracy. The connection between the emergence of statistics and the exercise of control by the state is an example of that (Prost 2010; Carpentier 2012). This variety of sources available to the historians and the possibility to combine them offers key opportunities to look at trends and patterns but also perceptions in higher education.

\section{The space of higher education}

The traditional focus on the history of higher education on the western world or on its influence on the rest of world is slowly shifting with an increase of research worldwide. Yulat remarks that "the short interregnum occupied by colonialism...in the long history of a continent that spans millennia, does not embody the sum total of all there is to know about African higher education" $(2005$, p.2). Rothblatt notes that "in approximately 800 years the 
university as an institution has served many cultures and societies" (1997, p.1). This incite us to look beyond the traditional boundaries of the history of higher education with for example studies on Latin America (Levy, 1986) or Asia with new key players such as China (Hayhoe 1996) and India (Rao 2014). Transnational histories with historical explorations of internationalisation (Geuna, 1998) as well as global and regional histories of higher education (Huisman and van Vught 2009) bring other layers to our long-term understanding of higher education.

\section{Cross-References}

British University Traditions

$>$ Community Colleges and the Massification of Higher Education

$>$ Elite, Mass, and High-Participation

$>$ Higher Education Inequality in Higher Education

$>$ Stratification in Higher Education

$>$ African University Traditions, Historical Perspective

$>$ Internationalization of Higher Education, Historical Perspective

\section{References}

Aldrich, R. 2003. The three duties of the historian of education. History of Education, 32(2): 133-143.

Anderson, R. D. 1992. Universities and elites in Britain since 1800. London: Macmillan.

Beach J. M. 2001. Gateway to opportunity: A History of the community college in the United States. Sterling, VA: Stylus Publishing.

Bevis, T. B. and Lucas, C. J. 2007. International students in American colleges and universities: A history. New York: Palgrave Macmillan.

Brennan, J. 2008. Higher education and social change. Higher Education, 56: 381-93.

Carpentier, V. 2012. Public-private substitution in higher Education: Has cost-sharing gone too far? Higher Education Quarterly, 66(4): 363-390.

Charle, C. 1994. La république des universitaires (1870-1940). Paris : Seuil.

Cobban, A.B. 1975. The Medieval universities. London: Methuen and Co.

Dyhouse, C. 2006. Students: A gendered history. London: Routledge.

Hutcheson, P. 2010. Writing through the Past: Federal Higher Education Policy. In The History of U.S. Higher Education: Methods for Understanding the Past, ed. M. Gasman, 172-186. New York: Routledge.

Geiger, R. L. 2015. The History of American higher education: Learning and culture from the founding to World War II. Princeton, N.J.: Princeton University Press.

Geuna, A. 1998. The Internationalisation of European universities: A Return to medieval roots. Minerva 36(3): 253-270. 
Goldin, C. and L. F. Katz 2008. The Race between education and technology. Cambridge, MA: Harvard University Press.

Halsey, A.H. 1992. The Decline of donnish dominion: the British academic professions in the twentieth century. Oxford: Oxford University Press.

Hammerstein, M. 1996. Relations with authority. In A History of the University in Europe. Volume 2: Universities in Early Modern Europe, ed. H. de Ridder-Symoens, 113-153. Cambridge: Cambridge University Press.

Hayhoe, R. 1996. China's universities 1985-1995: A Century of Cultural Conflict. New York: Garlard.

Huisman, J. and F. van Vught 2009. Diversity in European higher education: Historical trends and current policies. In Mapping the higher education landscape. Higher education dynamics, ed. F. van Vught, 17-38. Dordrecht: Springer.

Jarausch, K.H. 1983. The transformation of higher learning 1860-1930. Chicago: The University of Chicago Press.

Kerr, C. 1994. Higher education cannot escape history: Issues for the twenty-first century. Albany, NY: State University of New York Press.

Lowe, R. ed. 2009. The History of higher education: Major themes in education, 5 volumes. London: Routledge.

Lowe, R. and Yasuhara 2017. The Origins of Higher Learning: Knowledge Networks and the Early Development of Universities. London: Routledge.

Levy, D. C. 1986. Higher Education and the State in Latin America: private challenges to public dominance. Chicago: University of Chicago Press

Lulat, Y. G. M. 2005. A History of African higher education from Antiquity to the present: A Critical Synthesis. Wesport Connecticut and London: Praeger.

Madaus, J. W. 2011. The history of disability services in higher education. New Directions for Higher Education, 154:5-15.

Marginson, S. 2011. Higher education and public good. Higher Education Quarterly, 65:411433.

Marginson, S. 2016. The Dream is over: The crisis of Clark Kerr's Californian idea of higher education. Berkeley: University of California Press.

Musselin, C. 2004. The long march of French universities. London: RoutledgeFarmer.

Palfreyman, D. and T. Tapper. 2014. Reshaping the university: The rise of the regulated market in higher education (Oxford: Oxford University Press)

Perkin, H. 1984. The Historical perspective. In Perspectives on higher education: Eight disciplinary and comparative views, ed. B.R. Clark, 17-55. Berkeley \& Los Angeles: University of California Press. 
Perkin, H. 2007. History of Universities. In International Handbook of Higher Education, ed. J. J. F. Forest and P. G. Altbach, 159-205. Dordrecht: Springer.

Picard, E. 2009. L'histoire de l'enseignement supérieur français. Pour une approche globale. Histoire de l'éducation, 122: 11-33.

Piketty, T. 2014. Capital in the 21st Century. Cambridge MA: Harvard University Press.

Prost, A. 2010. Une histoire en chiffre de l'enseignement supérieur. Le mouvement Social 4: 31-46.

Rao, P. V. 2014. New perspectives in the history of Indian education. New Delhi, Orient Blackswan.

Rashdall, H. 1936. The Universities of Europe in the Middle Ages, eds. Powicke, F. M. and Emden, A. B. Oxford: Oxford University Press.

Rothblatt, S. 1997. The Modern university and its discontents. Cambridge: Cambridge University Press.

Sanderson, M. 1972. The Universities and British industry 1850-1970. London: Routledge \& Kegan Paul.

Scott, P. 2014. Robbins, the Binary policy and mass higher education. Higher Education Quarterly 68(2): 147-163.

Shattock, M. 2012. Making policy in British higher Education 1945-2011. Maidenhead: Open University Press.

Silver, H. 2006. Things change but names remain the same: Higher education historiography. History of Education, 35(1): 121-140.

Smith, W. A.; Altbach P. G. and K. Lomotey. 2002. The racial crisis in American higher education: Continuing challenges for the twenty-first century. Albany: State University of New York Press.

Szreter, S. 2011. History and public policy. In The public value of the humanities, ed. J. Bate, 219-231. London: Spubna.

Teixeira, P. 2009. Mass higher education and private institutions. In Higher education to 2030, Volume 2, Globalization, ed. OECD, 231-258. Paris: OECD.

Thelin J.R. 2004. A History of American higher education. Baltimore, MD: Johns Hopkins University Press.

Tight, M. 2012. Researching higher education. Maidenhead: Open University Press.

Tosh, J. 2006. The Pursuit of history. London: Pearson.

Trow, M. 1974. Problems in the transition from elite to mass higher education. Paris: OECD.

Välimaa, J. 2007. On traditions and historical layers in higher education. In Towards a cartography of higher education policy change: Festschrift in honour of Guy Neave, ed. J. Enders and F. A. van Vught, 67-76. Enschede: CHEPS. 
Vallance P. 2016. The historical roots and development of the civic university In The Civic University: The Leadership and Policy Challenges, ed. J. Goddard; E. Hazelkorn; L. Kempton and P. Vallance, 16-33. Cheltenham, UK: Edward Elgar.

Verger, J. 1992. Patterns. In A history of the University in Europe: Vol. 1. Universities in the Middle Ages, ed. W. Rüegg, 35-76. Cambridge: CUP.

von Oertzen, C. (2014) Science, gender and internationalism: women's academic networks, 1917-1955. Basingstoke: Palgrave Macmillan.

Watson, D. 2014. The Question of conscience: higher education and personal responsibility. London: Institute of Education Press.

Whyte, W. 2015. Redbrick: A social and architectural history of Britain's civic universities. Oxford: Oxford University Press. 